\title{
Impact of Employee Value Proposition on Hotel's Employee
}

Submitted Date :

14 April 2021

Tiurida Lily Anita*

Bina Nusantara University tiurida.anita@binus.ac.id

Accepted Date :

2 September 2021

Elang Kusumo

Pelita Harapan University elang.kusumo@uph.edu

Sarfilianty Anggiani

Trisakti University

Suggested Citation:

sarfilianty@trisakti.ac.id.

Pawar, A., \& Charak, K. S. (2014). a Study and Review of Employee Value Proposition : a Tool of Human Abstract:

Resource Management. Review Of Research, 3(6). http://ror.isrj.net/UploadedData/642.pdf

This study aims to determine the direct and indirect influence between employee value proposition (EVP), and employee satisfaction (ES) on employee productivity (EP) in the Hospitality Industry, during the Covid 19 pandemic. This research was conducted by conducting observations and surveys to several hotels around the Jakarta area. Respondents in this study were employees who worked at the Hotel as many as 133 respondents, with sampling techniques using purposive sampling, data collection was conducted with the dissemination of questionnaires and this research was conducted with a descriptive quantitative approach. The analysis technique used is path analysis. The results showed that EVP had a positive and significant direct and indirect effect on employee productivity.

Keywords: Employee Value Proposition, Employee productivity, Employee satisfaction.

\section{Abstrak:}

Penelitian ini bertujuan untuk mengetahui pengaruh langsung dan tidak langsung antara employee value proposition (EVP),dan kepuasan karyawan (ES) terhadap produktivitas karyawan (EP) di Industri Perhotelan, selama pandemi Covid 19. Penelitian ini dilakukan dengan melakukan observasi dan survey ke beberapa Hotel di sekitar wilayah Jakarta. Responden pada penelitian ini adalah karyawan yang bekerja di Hotel sebanyak 133 responden, dengan teknik pengambilan sampel menggunakan purposive sampling, pengumpulan data dilakukan dengan penyebaran kuesioner dan penelitian ini dilakukan dengan pendekatan deskriptif kuantitatif. Teknik analisis yang digunakan adalah analisis jalur. Hasil penelitian menunjukkan bahwa EVP berpengaruh langsung dan tidak langsung secara positif dan signifikan terhadap EP.

Keywords: Employee Value Proposition, Employee satisfaction, Employee productivity

JEL Classification : M31

*Corresponding Author 


\section{Latar Belakang}

Industri pariwisata dan perhotelan merupakan industri yang terpukul dan terdampak parah sejak virus corona dinyatakan pandemi pada 11 Maret 2020 (Gupta et al., 2020). Banyak hotel yang terpaksa tutup karena tidak adanya tamu (Hao et al., 2020). Kebijakan yang diterapkan oleh pemerintah pusat di Indonesia untuk menghambat penyebaran virus sangat berdampak pada seluruh lapisan masyarakat. Kebijakan korporasi yang mendukung kebijakan pemerintah mengadakan social distancing, membuat banyak perusahaan menutup operasional bisnis sehari-hari dalam upaya mencegah penyebaran virus. Sebagai industri yang didasarkan pada mobilitas dan interaksi manusia yang dekat karena sangat mengandalkan skill influence karyawan((Anggiani, 2017), industri pariwisata dan perhotelan tampaknya menjadi penerima manfaat utama dari pandemi dan semua efek yang menyertainya (Gallen, 2020). Hal ini akan sangat mempengaruhi performance hotel dan employee (Ramadhani et al., 2020).

Karakteristik hotel sebagai bagian dari industri perhotelan, yang menjual jasa sebagai produk utama, dikenal dengan intangibility-nya (Yang et al., 2015), inseparability (Garas, Sally Raouf Ragheb; Mahran, Amira Fouad Ahmed; Mohamed, Hassan; Mohamed, 2017) dan heterogenitas layanan (Xie et al., 2014), dimana karyawan, terutama karyawan yang berhubungan dengan pelanggan berfungsi sebagai fondasi untuk keberlangsungan brand hotel (Kusumo, E; Anita, TL; Anggiani, 2020). Dalam industri perhotelan, pengalaman merek pelanggan dan kesuksesan merek hotel sangat bergantung pada kinerja penyampaian layanan karyawan pada pertemuan layanan (Dhiman \& Arora, 2020). Ketika suatu organisasi mengkomunikasikan secara efektif tentang apa yang ada dalam program perusahaan untuk karyawan melalui EVP, hal itu secara halus dapat meningkatkan kepuasan karyawan (Pawar \& Charak, 2014) dan pada akhirnya meningkatkan produktivitas karyawan (Coker, 2011).

Industri hotel membutuhkan proposisi nilai karyawan. Value Proposition akan mengidentifikasi kebijakan, proses, dan program unik yang menunjukkan komitmen dan keseriusan perusahaan terhadap tingkat kepositifan pertumbuhan karyawan, pengakuan dan pengembangan manajemen. Penelitian yang dilakukan oleh Pawar dan Charak (2014) mengenai employee value proposition menyatakan bahwa EVP menciptakan keseimbangan antara kepuasan kerja karyawan dan kinerja karyawan dalam budaya kerja. EVP dapat digunakan sebagai alat branding ketenagakerjaan yang efektif karena menguraikan apa yang diinginkan karyawan untuk mencapai produktifitas kerja yang maksimal (Pawar \& Charak, 2014). Dengan lima elemen yang menjadi perhatian, yaitu; a). Kompensasi: Jumlah pendapatan dalam bentuk uang yang diterima karyawan terkait pekerjaan dan ketrampilan yang dimiliki, b). Manfaat: Kompensasi tidak langsung termasuk kesehatan, pensiun dan cuti, c). Pekerjaan: terkait kepuasaan yang dirasakan oleh karyawan dari pekerjaan yang dilakukan, d). Karir: Kesempatan berkembang di masa depan terkait dengan pekerjaan yang ditekuni, e). Afiliasi: Perasaan ikut memiliki karyawan terhadap perusahaan. EVP harus dapat dirasakan oleh karyawan, agar EVP berhasil, maka organisasi perusahaan harus membuat paket menarik bagi karyawan yang bekerja pada organisasi perusahaan (Michington, 2006). EVP akan meningkatkan kepuasan karyawan, hal ini didasarkan pada hubungan antara biaya karyawan, beban pekerjaan yang harus dilakukan, dan kualitas pengalaman kerja karyawan. Keseimbangan antara biaya, beban kerja dan kualitas inilah yang membangun keunggulan kompetitif bagi pengusaha dalam menarik dan mengurangi retensi karyawan.

Kepuasan karyawan dapat dikatakan sebagai faktor kunci yang berkontribusi terhadap kesejahteraan mental dan fisik karyawan(Meyer et al., 2004). Ini memiliki pengaruh yang besar terhadap aktivitas karyawan seperti produktivitas, ketidakhadiran, perilaku, perputaran dan hubungan karyawan (Cao et al., 2016). Colquitt, LePine, dan Wesson (2017) pada penelitian mereka menyatakan bahwa kepuasan karyawan diartikan sebagai keadaan emosi yang menyenangkan yang merupakan hasil penilaian seseorang atas pekerjaan yang telah dilakukan. Ini menjelaskan bagaimana perasaan dan pemikiran karyawan tentang pekerjaan mereka (Colquitt, J.A., LePine, A. and Wesson, 2017). Lebih lanjut dijelaskan bahwa tingkat kepuasan karyawan memiliki dua variabel yang terdiri dari variabel pemberi kerja dan variabel pribadi (Sageer, 2012). Variabel pemberi kerja terdiri dari pengembangan pemberi kerja, kebijakan kompensasi dan tunjangan, promosi dan pengembangan karir, lingkungan dan kondisi kerja, hubungan dengan supervisor, gaya kepemimpinan dan faktor lainnya. Sedangkan variabel kepuasan pribadi tergantung pada kepribadian, harapan, usia, pendidikan dan jenis kelamin. Oleh karena itu, bagi pengusaha dalam upaya mempertahankan karyawan bertalenta dan memiliki tingkat turnover karyawan yang lebih rendah, loyalitas dan kepuasan karyawan perlu dijaga sebagai prasyarat produktivitas. Penelitian ini mendefinisikan kepuasan karyawan sebagai sejauh mana pemahaman tentang kebahagiaan yang dirasakan karyawan ketika kebutuhannya terpenuhi.

Mohammad (2019) pada penelitiannya mengenai produktivitas karyawan, secara khusus menekankan pada keberadaan produktivitas karyawan sebagai faktor penting yang dapat diandalkan untuk dapat meningkatkan, memperkuat dan memelihara kinerja bisnis perusahaan. Ketiadaan tenaga kerja dapat membuat penilaian produktivitas karyawan menjadi negatif (Mohammad et al., 2019). Meski tidak bisa dipungkiri, terkadang bahkan saat karyawan masuk kerja, produktivitas bisa menurun. Lebih lanjut, produktivitas karyawan dapat didefinisikan sebagai seberapa banyak dan seberapa baik perusahaan menghasilkan dari sumber daya yang digunakan. Jika sebuah perusahaan berhasil menghasilkan lebih banyak atau lebih baik produk andalannya dari sumber daya yang sama, itu berarti peningkatan produktivitas. Pengertian produktivitas karyawan juga diartikan sebagai waktu yang digunakan secara aktif oleh karyawan untuk melaksanakan dan menghasilkan hasil yang diharapkan (Ferreira, 2010). Dalam penelitian ini produktivitas mengacu pada waktu yang dihabiskan oleh karyawan yang secara aktif menyelesaikan pekerjaan, untuk menghasilkan kinerja yang diinginkan dan diharapkan dari deskripsi pekerjaan karyawan. Dengan menyelesaikan pekerjaannya, seorang karyawan dapat merasakan 
Jurnal Bisnis dan Manajemen

http://jurnal.unmer.ac.id/index.php/jbm
Volume 8 No 2

2021

HIm. 197 - 201

kepuasan dan mendapatkan imbalan sebagai bagian dari program employee value proposition. Berdasarkan penjelasan tersebut maka tujuan penelitian ini adalah untuk mengetahui pengaruh employee value proposition terhadap kepuasan karyawan, untuk mengetahui pengaruh kepuasan karyawan terhadap produktivitas kerja karyawan, dan untuk mengetahui pengaruh langsung dan tidak langsung terhadap produktivitas paryawan dari proposisi nilai Karyawan dan produktivitas karyawan.

\section{Methodology}

Penelitian ini menggunakan pendekatan deskriptif kuantitatif. Pendekatan deskriptif kuantitatif dilakukan melalui survei penelitian dengan cara mengumpulkan kuesioner kepada responden yang merupakan karyawan hotel di Jakarta, sebanyak 133 repsonden. Pengambilan sampel penelitian menggunakan non-probability sampling jenis Purposive Sampling yaitu teknik untuk menentukan sampel penelitian dengan pertimbangan, kriteria, atau karakteristik khusus yang bertujuan untuk memperoleh data yang lebih presentatif. Berdasarkan sampel dalam model struktural dan kondisi laten tertentu, ukuran sampel dapat dianggap sepuluh kali jumlah total jalur struktural (Hair et al., 2019). Penelitian ini memiliki total 3 jalur struktural, sehingga berdasarkan ukuran sampel yang diusulkan oleh Hair dibutuhkan minimal $3 \times 10=30$ sampel. Teknik Analisa data yang digunakan dalam penelitian ini adalah teknik analisis jalur atau path analysis.

\section{Hasil}

Pengumpulan data dilakukan dengan menggunakan kuisioner survey yang ditujukan kepada karyawan hotel berbintang di Jakarta dan sekitarnya. Kuesioner disebarkan melalui aplikasi whatsapp menggunakan google form dan diisi oleh 133 responden, dan berdasarkan waktu pengumpulan data dikumpulkan hanya sekali atau disebut cross-sectional studies (Sekaran \& Bougie, 2016), periode waktu pengumpulan data dilakukan selama bulan Maret 2021. Penelitian ini menggunakan Skala Likert lima poin untuk mengukur konstruksi utama model konseptual. Koefisien Cronbach Alpha juga diuji untuk memastikan tingkat reliabilitas konstruk yang baik, dan semua konstruk ditemukan memiliki nilai yang dapat diterima lebih tinggi dari 0,70 (Ghozali, I., \& Latan, 2015).

Hasil Demographis adalah sebagai berikut: responden yang mengisi kuesioner terdiri dari 67 responden (49.6\%) laki-laki dan 66 responden (50.4\%) wanita, dengan rentang usia mayoritas responden berada pada rentang usia $25-34$ tahun (51 orang). Masa kerja responden terbanyak terdapat pada rentang masa kerja $<5$ tahun sebanyak 57 responden atau $42,9 \%$, dan bidang kerja responden terbanyak adalah pada bagian Food \& Beverage sebanyak 41 responden atau $30,8 \%$.

Penelitian ini menggunakan pendekatan model persamaan struktural (SEM) dengan bantuan Smart PLS 3.2.8 perangkat lunak (Hair et al., 2019). Dalam analisis SEM-PLS akan diterapkan dua tahap pemodelan, yaitu tahap pertama measurement model diuji untuk memastikan tingkat kesesuaian model yang memadai serta validitas dan reliabilitas konstruk. Kemudian hipotesis utama penelitian ini diuji pada tahap kedua yaitu structural model.

Hasil pengukuran convergent validity menunjukkan bahwa nilai semua item memiliki nilai loading factor yang lebih besar dari 0,5. Dapat disimpulkan bahwa semua indikator konstruksi variabel; EVP, Employee satisfaction dan Employee productivity berlaku. Nilai AVE pada setiap variabel laten lebih besar dari 0,5 yang berarti setiap variabel dapat menjelaskan $50 \%$ atau lebih variabel tersebut. Artinya setiap variabel dinyatakan valid dan memenuhi kriteria convergent validity, seperti yang ditunjukkan pada Tabel 1. Pengujian indikator reflektif menunjukkan hasil baik untuk mengukur konstruk berdasarkan prinsip bahwa setiap indikator harus berkorelasi kuat dengan konstruknya. Hal ini dilakukan dengan menguji hasil nilai validitas menggunakan kriteria cross-loading dan Fornell-Larcker (Ghozali, I., \& Latan, 2015). Terlihat pada tabel 2, nilai Construct Reliability dari setiap variabel lebih besar dari 0,7 . Nilai cross loading semua indikator pada konstruknya memiliki nilai yang lebih besar dari pada indikator loading factor pada konstruk lain. Sehingga dapat disimpulkan bahwa semua konstruk yang tidak memiliki hubungan, tidak berhubungan dan memenuhi kriteria discriminant validity. Hasil validitas diskriminan masing-masing variabel laten dapat dilihat pada tabel 2, hasil Fornell-Larcker memenuhi kriteria, kemudian semua variabel laten yang dimasukkan dalam penelitian ini dinyatakan memenuhi persyaratan discriminant validity. Dengan demikian, dapat disimpulkan bahwa semua variabel dianggap reliabel untuk digunakan pada pengujian hipotesis.

Tabel 1. Construct Reliability and Validity

\begin{tabular}{lrrrr}
\hline & Cronbach's Alpha & \multicolumn{1}{c}{ rho_A } & Composite Reliability & Average Variance Extracted \\
\hline EP & 0,864 & 0,877 & 0,901 & 0,646 \\
ES & 0,925 & 0,926 & 0,938 & 0,626 \\
EVP & 0,821 & 0,824 & 0,894 & 0,739 \\
\hline
\end{tabular}

Sumber: Data Diolah (2021)

Tabel 2. Fornell-Larcker Criterion 


\begin{tabular}{|c|c|c|c|}
\hline & & & \\
\hline EP & 0,804 & & \\
\hline ES & 0,607 & 0,791 & \\
\hline EVP & 0,519 & 0,648 & 0,860 \\
\hline
\end{tabular}

Sumber: Data Diolah (2021)

Tabel 3. R Square

\begin{tabular}{lrrr} 
& \multicolumn{2}{c}{ R Square } & R Square Adjusted \\
\cline { 2 - 3 } & EP & 0,396 & 0,387 \\
ES & 0,420 & 0,415 \\
\hline
\end{tabular}

Sumber: Data Diolah (2021)

Tabel 4. Direct Effect, Indirect Effect and Total Effect

\begin{tabular}{lrrrrr} 
& Direct Effect & P Values & $\begin{array}{r}\text { T Statistics } \\
(\text { (O/STDEV|) }\end{array}$ & Indirect Effect & Total Effect \\
ES -> EP & 0.467 & 0.000 & 4.034 & & \\
EVP >> EP & 0.217 & 0.033 & 2.142 & & \\
EVP > ES & 0.648 & 0.000 & 9.435 & $0.648 \times 0.467=$ & $0.217+0.302=$ \\
EVP > EP melalui ES & & & & 0.302 & 0.519 \\
\hline
\end{tabular}

Sumber: Data Diolah (2021)

Pada tabel 3 menunjukkan nilai R-square untuk setiap variabel dependen (endogen). Nilai R-square untuk persentase employee value proposition (EVP) yang dapat dijelaskan oleh employee satisfaction (ES) adalah $42,0 \%$ dan sisanya $58 \%$ dijelaskan oleh variabel lain yang tidak diteliti dalam penelitian ini. Sedangkan R-square untuk variable Employee productivity (EP) adalah 0,396 artinya persentase yang dapat dijelaskan oleh Employee satisfaction adalah $39.6 \%$ dan sisanya $60.4 \%$ dijelaskan oleh variabel lain yang tidak diteliti dalam penelitian ini.

Pengujian hipotesis dilakukan dengan Uji t statistik, yaitu untuk menguji pengaruh antar variabel. T Statistik merupakan pernyataan nilai signifikansi hubungan antara variabel satu dengan variabel lainnya (tingkat signifikansi diambil pada tingkat kesalahan $5 \%$ ) dan nilai T statistik 1.96, sehingga untuk dapat dinyatakan bahwa setiap variabel memiliki hubungan yang signifikan, maka nilai T Statistik harus di atas 1,96.

Hasil koefisien jalur dirangkum pada Tabel 4, terlihat bahwa nilai t statistik masing-masing variabel lebih dari 1,96. Variabel EVP berpengaruh positif dan signifikan terhadap Employee satisfaction dengan nilai t Statistik $9.435>1,96$. sehingga H1 diterima. Hal ini sesuai dengan penelitian yang dilakukan oleh Ahmad Ikram Ajmain Bin Abu Hassan (2014), dengan judul penelitian Impact Of Employee value proposition Towards Job Satisfaction Of Petronas Human Capital Management Staff. Hasil penelitian membuktikan bahwa pelaksanaan EVP yang terdiri dari Rewards, Growth \& Trust pada perusahaan Petronas mempengaruhi kepuasan kerja karyawan (Hassan, 2014).

\section{Pembahasan}

Variabel Employee satisfaction berpengaruh positif dan signifikan terhadap Employee productivity, dengan nilai $t$ statistik $4.034>1.96$. sehingga, H2 diterima. Hal ini sesuai dengan penelitian Sageer et. Al (2012), dalam judul Identification of Variables Affecting Employee satisfaction and Their Impact on the Organization. Sageer et al, menyatakan bahwa faktor pengembangan organisasi, faktor keamanan pekerjaan, faktor tugas kerja, Kebijakan kompensasi dan faktor manfaat serta peluang yang memberikan kepuasan bagi karyawan seperti promosi dan pengembangan karier dapat meningkatkan produktivitas karyawan (Sageer, 2012).

Besar pengaruh langsung dari employee value proposition terhadap employee productivity adalah 0.217 . Sedangkan untuk pengaruh tidak langsung adalah 0.302. Dapat disimpulkan bahwa pengaruh tidak langsung dari employee value proposition terhadap employee productivity melalui employee satisfaction lebih besar. Sehingga, dapat dijelaskan bahwa employee satisfaction merupakan bukan merupakan variable moderating bagi employee productivity. Berdasarkan hal ini $\mathrm{H} 3$ diterima.

\section{Kesimpulan}

Berdasarkan hasil pengujian analisis pemodelan persamaan struktural dapat disimpulkan sebagai berikut; hubungan antara employee value proposition (EVP) pada employee satisfaction terbukti memiliki pengaruh yang signifikan dan positif. Pengaruh signifikan juga terdapat pada employee satisfaction (ES) pada employee productivity (EP). Employee value proposition memiliki pengaruh tidak langsung terhadap employee productivity melalui employee satisfaction yang besar. Sehingga, dapat dijelaskan bahwa employee satisfaction bukan merupakan variable moderating bagi employee productivity. Berdasarkan hal ini dapat disarankan agar perusahaan terutama bidang hotel agar menjaga kepuasan karyawan dalam bekerja dengan lebih mendorong pengaplikasian employee value proposition (EVP) dalam kegiatan rutin di manajemen. Pemberian kompensasi yang sesuai, benefit serta manfaat yang bisa diperoleh karyawan ketika bekerja di hotel harus lebih 
diutamakan untuk dijelaskan dan dilaksanakan dengan baik. Penelitian selanjutnya untuk variable EVP dapat dilaksanakan di industry hospitality lainnya selain hotel, misalnya pada restaurant dan rumah sakit. Dengan menambahkan variabel kepuasan konsumen sebagai variable terikat untuk mengukur apakan EVP dan kepuasan karyawan dapat mempengaruhi kepuasan konsumen terhadap layanan yang diberikan perusahaan.

\section{Daftar Pustaka}

Ahmad Ikram Ajmain Bin Abu, H. (2014). Impact Of Employee Value Proposition Towards Job Satisfaction Of Petronas Human Capital Management. In Faculty Of Business Management University Technology Mara (Issue July).

Anggiani, S. (2017). Skill Influence on Employee Performance (Empirical Study of Frontlines three Star Hotels in Jakarta). International Journal of Management and Applied Science (IJMAS), 12, 14-18.

Cao, X., Guo, X., Vogel, D., \& Zhang, X. (2016). Exploring the influence of social media on employee work performance. Internet Research, 26(2), 529-545. https://doi.org/10.1108//ntR-11-2014-0299

Coker, B. L. S. (2011). Freedom to surf: The positive effects of workplace Internet leisure browsing. New Technology, Work and Employment, 26(3), 238-247. https://doi.org/10.1111/j.1468-005X.2011.00272.x

Colquitt, J.A., LePine, A. and Wesson, M. J. (2017). Organizational Behaviour: Improving Performance and Commitment in the Workplace (5th ed.). McGraw - Hill Education.

Dhiman, P., \& Arora, S. (2020). A conceptual framework for identifying key employee branding dimensions: A study of hospitality industry. Journal of Innovation and Knowledge, 5(3), 200-209. https://doi.org/10.1016/j.jik.2019.08.003

Ferreira, A. \& P. du T. (2010). Effect of online social networking on employee productivity. SA Journal of Information Management, 11(January), 1-16. http://www.sajim.co.za/index.php/SAJIM/article/viewArticle/397

Gallen, S. (2020). The response of tourism businesses vis-à-vis the economic ramifications of SARS-CoV-2.

Garas, Sally Raouf Ragheb; Mahran, Amira Fouad Ahmed; Mohamed, Hassan; Mohamed, H. (2017). Internal corporate branding impact on employees' brand supporting behaviour. Journal of Product \& Brand Management, 1-31. https://doi.org/10.1108/EUM0000000001126

Ghozali, I., \& Latan, H. (2015). Partial Least Squares Concepts, Techniques and Applications using the SmartPLS 3.0 Program (Edition 2). Undip.

Gupta, D., Bhatt, S., Gupta, M., \& Tosun, A. S. (2020). Future smart connected communities to fight COVID-19 outbreak. ArXiv, 100342. https://doi.org/10.1016/j.iot.2020.100342

Hair, J. F., Risher, J. J., Sarstedt, M., \& Ringle, C. M. (2019). When to use and how to report the results of PLS-SEM. European Business Review, 31(1), 2-24. https://doi.org/10.1108/EBR-11-2018-0203

Hao, F., Xiao, Q., \& Chon, K. (2020). COVID-19 and China's Hotel Industry: Impacts, a Disaster Management Framework, and Post-Pandemic Agenda. International Journal of Hospitality Management, 90(June), 102636. https://doi.org/10.1016/j.jjhm.2020.102636

Kusumo, E; Anita, TL; Anggiani, S. (2020). Corporate Language as Corporate Strategy to Sustainable Brand in Indonesia (Case of Starbuck Language). 8th ITSA Biennial Conference 2020, 255-262.

Meyer, J. P., Becker, T. E., \& Vandenberghe, C. (2004). Employee commitment and motivation: A conceptual analysis and integrative model. Journal of Applied Psychology, 89(6), 991-1007. https://doi.org/10.1037/0021-9010.89.6.991

Michington, B. (2006). Your Employer Brand - Attract, Engage, Retain. Collective Learning.

Pawar, A., \& Charak, K. S. (2014). a Study and Review of Employee Value Proposition: a Tool of Human Resource Management. Review Of Research, 3(6). http://ror.isrj.net/UploadedData/642.pdf

Ramadhani, F. E., Malang, U. M., Malang, U. M., \& Malang, U. M. (2020). Jurnal Bisnis dan Manajemen TALENT MANAGEMENT DAN KNOWLEDGE MANAGEMENT TERHADAP KINERJA. 7(2), 126-132.

Sageer, A. (2012). Identification of Variables Affecting Employee satisfaction and Their Impact on the Organization. IOSR Journal of Business and Management, 5(1), 32-39. https://doi.org/10.9790/487x-0513239

Sekaran, U., \& Bougie, R. (2016). Reserach Methods for Bussiness A Skill-Bulding Approach. 1-447.

Xie, L. S., Peng, J. M., \& Huan, T. C. (2014). Crafting and testing a central precept in service-dominant logic: Hotel employees' brand-citizenship behavior and customers' brand trust. International Journal of Hospitality Management, 42, 1-8. https://doi.org/10.1016/j.ijhm.2014.05.011

Yang, J. Te, Wan, C. S., \& Wu, C. W. (2015). Effect of internal branding on employee brand commitment and behavior in hospitality. Tourism and Hospitality Research, 15(4), 267-280. https://doi.org/10.1177/1467358415580358 